NBER WORKING PAPER SERIES

\title{
LEGAL INSTITUTIONS AND FINANCIAL DEVELOPMENT
}

\author{
Thorsten Beck \\ Ross Levine \\ Working Paper 10126 \\ http://www.nber.org/papers/w10126 \\ NATIONAL BUREAU OF ECONOMIC RESEARCH \\ 1050 Massachusetts Avenue \\ Cambridge, MA 02138 \\ December 2003
}

This paper was prepared for Claude Menard and Mary Shirley, eds., Handbook of New Institutional Economics, Kluwer Dordrecht (The Netherlands), forthcoming (2004). We have received very helpful guidance from Mary Shirley, Andrei Shleifer, and three anonymous referees. All remaining errors and omissions, however, are our responsibility. This chapter's findings, interpretations, and conclusions are entirely those of the authors and do not necessarily represent the views of the World Bank, its Executive Directors, or the countries they represent. The views expressed herein are those of the authors and not necessarily those of the National Bureau of Economic Research.

C2003 by Thorsten Beck and Ross Levine. All rights reserved. Short sections of text, not to exceed two paragraphs, may be quoted without explicit permission provided that full credit, including $(\mathrm{C}$ notice, is given to the source. 
Legal Institutions and Financial Development

Thorsten Beck and Ross Levine

NBER Working Paper No. 10126

December 2003

JEL No. K40, K22, G18, P14

\section{$\underline{\text { ABSTRACT }}$}

This paper provides a concise, selective review of research on the role of legal institutions in shaping the operation of financial systems. While a burgeoning literature finds that financial development exerts a first-order impact on economic growth, the law and finance literature seeks to understand the role of legal institutions in explaining international differences in financial systems. Considerable research dissects, critiques, and debates the influence of investor protection laws, the efficiency of contract enforcement, and private property rights protection on the effectiveness of corporate governance, the efficient allocation of capital, and the overall level of financial development. Furthermore, legal scholars, political scientists, historians, and economists are questioning and assessing the importance of historically determined differences in legal traditions in shaping national approaches to investor protection laws, contract enforcement, and property rights. The field of law and finance promises to be a contentious and important area of inquiry in coming years.

Thorsten Beck

World Bank

Washington, DC 20433

tbeck@worldbank.org

Ross Levine

Finance Department, Room 3-257

Carlson School of Management

University of Minnesota

321 19th Avenue South

Minneapolis, MN 55455

and NBER

rlevine@csom.umn.edu 


\section{INTRODUCTION}

A burgeoning literature finds that financial development exerts a first-order impact on long-run economic growth. Levine and Zervos (1998) show that banking and stock market development are good predictors of economic growth. ${ }^{1}$ At the microeconomic level, DemirgucKunt and Maksimovic (1998) and Rajan and Zingales (1998) find that financial institutions are crucial for firm and industrial expansion. While disagreements remain, the bulk of existing evidence points to a strong finance-growth nexus.

The finding that financial development influences economic growth raises critical questions, such as why do some countries have well-developed growth-enhancing financial systems, while others do not? Why have some countries developed the necessary investor protection laws and contract-enforcement mechanisms to support financial institutions and markets, while others have not?

The law and finance theory focuses on the role of legal institutions in explaining international differences in financial development (La Porta, Lopez-de-Silanes, Shleifer, and Vishny, 1997, 1998, 2000a, henceforth LLSV). The first part of the law and finance theory holds that in countries where legal systems enforce private property rights, support private contractual arrangements, and protect the legal right of investors, savers are more willing to finance firms and financial markets flourish. In contrast, legal institutions that neither support private property rights nor facilitate private contracting inhibit corporate finance and stunt financial development.

The second part of the law and finance theory emphasizes that the different legal traditions that emerged in Europe over previous centuries and were spread internationally through conquest, colonization, and imitation help explain cross-country differences in investor protection, the contracting environment, and financial development today. More specifically, legal theories 
emphasize two inter-related mechanisms through which legal origin influences finance (Hayek, 1960). The "political" mechanism holds that (a) legal traditions differ in terms of the priority they attach to private property vis-à-vis the rights of the State and (b) the protection of private contracting rights forms the basis of financial development (LLSV, 1999). The "adaptability" mechanism stresses that (a) legal traditions differ in their formalism and ability to evolve with changing conditions and (b) legal traditions that adapt efficiently to minimize the gap between the contracting needs of the economy and the legal system's capabilities will more effectively foster financial development than more rigid systems (Merryman, 1985).

Countervailing theories and evidence challenge both parts of the law and finance theory. Many researchers accept that effective investor protection facilitates efficient corporate financing and growth-enhancing financial development, but reject the law and finance's view that legal origin is a central determinant of investor protection laws and financial development (Roe, 1994; Pagano and Volpin, 2001; Rajan and Zingales, 2003). Alternatively, some studies do not critique the role of legal origin. Instead, although abundant evidence emphasizes the importance of investor protection laws, recent studies question whether changes in investor protection laws drove the evolution of corporate ownership and financial development in the United Kingdom and Italy (Franks, et al., 2003; Aganin and Volpin, 2003).

Given debates about the role of legal institutions in shaping financial development, the remainder of the Chapter is organized as follows. Section 2 describes the law and finance theory along with skeptical and competing views. ${ }^{2}$ Section 3 reviews empirical evidence on both parts of the law and finance view. That is, we assess (i) whether legal origin differences account for crosscountry variations in property rights protection, support of private contractual arrangements, investor protection laws and financial development and (ii) the degree to which cross-country differences in investor protection laws explain differences in corporate finance and financial 
development. Besides examining supportive and conflicting evidence on these two parts of the law and finance theory, we also summarize recent findings on the mechanisms - the politics and adaptability mechanisms -- through which law and finance may be related.

\section{LEGAL THEORIES OF FINANCIAL DEVELOPMENT}

This section describes the law and finance theory. After briefly discussing how legal institutions may influence financial development, we discuss theories of how historically determined differences in legal heritage continue to shape private property rights protection, investor protection laws, and financial development. We devote considerable space to tracing the historical evolution of legal institutions because the law and finance theory stresses the link between legal origin and financial development today. Furthermore, this section describes two mechanisms through which legal origin may influence the contracting environment: the political and adaptability mechanisms. Finally, we review countervailing views that question the law and finance theory.

\subsection{Law, Enforcement, and Financial Development}

The first part of the law and finance theory stresses that legal institutions influence corporate finance and financial development (LLSV, 1998). As LLSV (2000a) emphasize, the law and finance view follows naturally from the evolution of corporate finance theory during the past half century. Modigliani and Miller (1958) view debt and equity as legal claims on the cash flow of firms. Jensen and Meckling (1976) stress that statutory laws and the degree to which courts enforce those laws shape the types of contracts that are used to address agency problems. Furthermore, as summarized by Hart (1995), financial economists have increasingly focused on (i) the control rights that financial securities bring to their owners and (ii) the impact of different legal rules on corporate control. From this perspective, we may view finance as a set of contracts. Thus, 
a country's contract, company, bankruptcy, and securities laws, and the enforcement of these laws fundamentally determine the rights of securities holders and the operation of financial systems.

At the firm level, Shleifer and Vishny (1997) note both that inside managers and controlling shareholder are frequently in a position to expropriate minority shareholders and creditors and that legal institutions play a crucial role in determining the degree of expropriation. Expropriation may include theft, as well as transfer pricing, asset stripping, the hiring of family members, and other "perquisites" that benefit insiders at the expense of minority shareholders and creditors (LLSV, 2000a). The law and finance theory emphasizes that cross-country differences in (i) contract, company, bankruptcy, and securities laws, (ii) the legal systems' emphasis on private property rights, and (iii) the efficiency of enforcement influence the degree of expropriation and hence the confidence with which people purchase securities and participate in financial markets.

Within the broad vision that legal institutions influence corporate finance and financial development, there are differing opinions regarding the degree to which the legal system should simply support private contractual arrangements and the degree to which the legal system should have specific laws concerning shareholder and creditor rights. Coasians hold that the legal system should simply enforce private contracts. Effective legal institutions allow knowledgeable and experienced financial market participants to design a vast array of sophisticated private contracts to ameliorate complex agency problems (Coase, 1960; Stigler, 1964; Easterbrook and Fischel, 1991). For this to work effectively, however, courts must enforce private contracts impartially and have both the ability and willingness to read complex contracts and verify technically intricate clauses that trigger specific actions (Glaeser, et al., 2001, p. 853). Given the difficulty in enforcing complex private contracts, there are potential advantages to developing company, bankruptcy, and securities laws that provide a framework for organizing financial transactions and protecting minority shareholders and creditors. While standardization may improve efficiency by 
lower the transactions costs associated with many financial market contracts, the imposition of too rigid a framework may curtail customization and thereby hinder efficient contracting. ${ }^{3}$ Whether assuming a Coasian reliance on enforcing complex private contracts or an approach that augments the support of private contracts with company, bankruptcy, securities laws, etc., the law and finance view's first part argues that the degree of protection of private investors is a crucial determinant of financial development.

\subsection{The Historical Development of Europe's Legal Systems}

The second part of the law and finance theory stresses that a country's legal heritage shapes its approach to property rights, private contracting, investor protection, and hence financial development. Comparative legal scholars note that the world's major legal families were formed in Europe over many centuries and then spread internationally. Thus, we begin our discussion with Roman law.

Hayek (1960) notes that when Emperor Justinian had the Roman law compiled in the sixth century, he attempted to implement two substantive modifications. First, while Roman law placed the law above all individuals, the Justinian texts placed the emperor above the law. Second, Justinian broke with Roman law by attempting to eliminate jurisprudence. Roman law had developed over centuries on a case-by-case basis, adjusting from the needs of a small farmer community to the needs of a world empire with only a minor role left for formal legislation. Justinian changed this doctrine and " $\ldots$ asserted for himself a monopoly, not only over all lawmaking power, but over legal interpretations." (Dawson, 1968, p.22). This "Justinian deviation" did not take root; jurisprudence continued to shape the law.

From the $15^{\text {th }}$ century, France's legal system evolved as a regionally diverse mélange of customary law, law based on the Justinian texts, and case law (Dawson, 1968, p. 349). Three 
observations are notable. First France had a very fragmented legal system. ${ }^{4}$ Second, although courts must have debated the appropriate application of conflicting Roman and customary law as new circumstances emerged, these deliberations generally occurred in private and without the same public, scholarly debates seen in Germany or England (Dawson, 1968, p. 286-302). Third, by the $18^{\text {th }}$ century, there was a notable deterioration in the integrity and prestige of the judiciary. The Crown sold judgeships to rich families and the judges unabashedly promoted the interests of the elite and impeded progressive reforms. ${ }^{5}$

Unsurprisingly, the French Revolution turned its fury on the judiciary and quickly strove to (a) place the State above the courts and (b) eliminate jurisprudence. ${ }^{6}$ Codification under Napoleon supported the unification and strengthening of the State and relegated judges to a minor, bureaucratic role. According to the theory underlying the French Civil Code, the legislature drafts laws without gaps, so judges do not make law by interpreting existing laws. The theory is that the legislature does not draft conflicting laws, so that judges do not make law by choosing between laws. The theory is that the legislature drafts clear laws so that judges do not make law by giving meaning to ambiguous laws. Like Justinian, Napoleon sought a code that was so clear, complete, and coherent that there would be no need for judges to deliberate publicly about which laws, customs, and past experiences apply to new, evolving situations. ${ }^{7}$ Furthermore, this approach required a high degree of procedural formalism to reduce the discretion of judges in regulating the presentation of evidence, witnesses, arguments, and appeals (Schlesinger, et al., 1988).

There are conflicting views on the success of the Napoleonic Code's goal of eliminating jurisprudence. Merryman $(1985,1996)$ argues that the Napoleonic doctrine was a temporary, largely theoretical "deviation" from two thousand years of a legal tradition built on jurisprudence. Indeed, the lead draftsman of the Code recognized explicitly that the legislature could not revise the Code sufficiently rapidly to handle efficiently the myriad of changing problems that arise in a 
dynamic nation. In contrast to theory, the French courts eventually built an entire body of tort law on the basis of Article 1382 of the Code Napoleon that states that one whose act injures another must compensate that person. In contrast to theory, French courts have used case law to recast the law of unjust enrichment, alter the law on obligations, re-work the law of contract regarding gifts, and change the system of administrative law (Dawson, 1968, 400-415). From this perspective, while the theory of the Napoleonic code rejected jurisprudence and embraced judicial formalism, practicalities in conjunction with a legal tradition grounded in jurisprudence produced in France a legal system that has increasingly employed judicial discretion over the last two centuries and thereby circumvented inefficient qualities of the Code.

Others disagree and argue that antagonism toward jurisprudence and the exaltation of the role of the state produced a comparatively static, rigid legal tradition. ${ }^{8}$ The French situation encouraged the development of easily verifiable "bright-line-rules" that do not rely on the discretion of judges (Glaeser and Shleifer, 2002). While simple and clear, Johnson et al. (2000) argue that bright-line-rules and excessive judicial formalism may not allow judges sufficient discretion to apply laws fairly to changing conditions and therefore not support evolving commercial needs.

Turning to Germany, Bismarck -- like Napoleon -- unified the country (in 1871) and placed a high priority on unifying the courts through codification. Although Bavaria and Prussia codified parts of the law during the $18^{\text {th }}$ century, it was Bismarck's decision in 1873 to codify and unify the whole of private law in Germany that led to the adoption of the German civil law in 1900.

The parallels between France and Germany's legal history, however, can be exaggerated. Unlike in France, German courts have published (since at least the $16^{\text {th }}$ century) comprehensive deliberations that illustrated how courts weighted conflicting statutes, resolved ambiguities, and 
addressed changing situations (Dawson, 1968). Law faculties at German universities worked directly with courts and tried to reconcile emerging situations with the logic of the Justinian texts. Through active debate between scholars and practitioners, Germany developed a dynamic, common fund of legal principles that then formed the basis for codification in the $19^{\text {th }}$ century.

Moreover, in contrast to the revolutionary zeal and antagonism toward judges that shaped the Napoleonic Code, German legal history shed a much more favorable light on jurisprudence and explicitly rejected France's approach. ${ }^{9}$ Thus, the German Code "was not intended to abolish prior law and substitute a new legal system; on the contrary, the idea was to codify those principles of German law that would emerge from careful historical study of the German legal system.” (Merryman, 1985, p.31)

Whereas the Napoleonic code was designed to be immutable, the Bürgerliches Gesetzbuch was designed to evolve. For instance, France technically denies judicial review of legislative actions, while Germany formally recognizes this power and German courts actively exercise it (Glendon, et al., 1982, p.57). Similarly, in terms of adjudicating disputes involving the government, France's administrative courts are within the executive branch itself. In Germany, the judiciary handles these disputes. Further, the Court of Cassation in France was originally viewed as an institution to assist the legislature. It had powers to quash decisions, but not decide cases. This is different from the Bundesgerichtshof in Germany that can reverse, remand, modify, or enter final judgment on cases, and where judicial decision-making process tends to be more openly debated. ${ }^{10}$ Thus, while codification had a similar role in Germany and France in unifying the country and reasserting the power of the central state, Germany had a very different approach toward jurisprudence.

The Scandinavian Civil law developed relatively independently from the other traditions in the $17^{\text {th }}$ and $18^{\text {th }}$ centuries and is less closely linked with Roman Civil law than the French or 
German traditions (Zweigert and Kötz, 1988, henceforth ZK). Moreover, neither the construction, nor the subsequent evolution, of the Scandinavian Civil law has been used to eliminate jurisprudence and boost the role of the State relative to private investors to the same extent as in the French Civil law (LLSV, 1998). ${ }^{11}$ While extensive, active scholarship examines differences between French, German, and British law, comparatively less effort has been devoted to understanding the functioning of the Scandinavian civil law tradition and its influence on the development of financial systems in Scandinavia.

The historical development of the British common law is unique both in terms of (a) the relationship between the State and the Courts and (b) jurisprudence. From 1066, the English law evolved based on the resolution of specific disputes and increasingly stressed the rights of private property. While landholding rights in England were originally based on William I's feudal system, the courts developed legal rules that treated large estate holders as private property owners and not as tenants of the king. Indeed, the common law at the dawn of the $17^{\text {th }}$ century was principally a law of private property (e.g., Littleton, 1481, and Coke, 1628).

The English Common law asserted its independence from the State during the tumultuous $16^{\text {th }}$ and $17^{\text {th }}$ centuries, during the great conflict between Parliament and the English kings. The Crown attempted to reassert feudal prerogatives and sell monopoly rights to cope with budgetary shortfalls. Parliament (composed mostly of landowners and wealthy merchants) along with the courts took the side of the property owners against the Crown. While King James I argued that royal prerogative superseded the common law, the courts asserted that the law is king, Lex, Rex. This political struggle culminated in 1688 , when the Stuarts were thrown out. This allowed the courts to place the law above the Crown and limit the Crown's power to alter property rights and grant monopoly rights. ${ }^{12}$ 
Besides the power of the law vis-à-vis the State, the Common law's history is also importantly different from France's in terms of jurisprudence and legal formalism. Unlike in

France, the courts in England were frequently viewed more favorably and sometimes as supporters of progressive reforms, so that judges were afforded greater discretion. In terms of legal formalism, English law typically imposes less rigid and formalistic requirements on the presentation of evidence, witnesses, etc., and instead offers judges greater latitude (Schlesinger, et al., 1988). In terms of jurisprudence, the English common law tradition is almost synonymous with judges having broad interpretation powers and with courts molding and creating law as circumstances change. The common law is obsessed with facts and deciding concrete cases, rather than adhering to the logical principles of codified law. Thus, the popular dictum: "The life of the law has not been logic: it has been experience." (ZK, 1998, p. 181). Unlike the Napoleonic doctrine, judges continually - and as a matter of general practice -- shape the law through their decisions.

\subsection{The Spread of Europe's Legal Systems}

The English, French, and German legal traditions spread throughout the world through conquest, colonization, and imitation. Napoleon secured the adoption of the Code in all conquered territories, including Italy, Poland, the Low Countries, and the Habsburg Empire. Also, France extended her legal influence to parts of the Near East, Northern and Sub-Saharan Africa, Indochina, Oceania, French Guyana, and the French Caribbean islands during the colonial era. Furthermore, the French Code heavily influenced the Portuguese and Spanish legal systems, which helped spread the French legal tradition to Central and South America. The English common law spread through colonization and conquest to all corners of the world. The Austrian and Swiss civil codes were developed at the same time as the German civil code and the three influenced each other heavily. In turn, Czechoslovakia, Hungary, Yugoslavia, and Greece relied 
on German civil law in formulating and modernizing their legal systems in the early part of the $20^{\text {th }}$ century. The German Civil Code was not imposed but exerted a big influence on Japan. At the end of the $19^{\text {th }}$ century, Japan looked toward Europe as it sought to draft a commercial code. While Japan considered the French civil code, Japanese legal scholars were attracted to the systematic theorizing of the German code and its emphasis on fitting the evolution of the law into a country's historical context (ZK, 1998, p. 296-302.) The Japanese commercial code of 1899 is squarely based on the German counterpart. Although Japan came under the influence of the Common law during the post World War II occupation period (especially in the area of public law), it is not uncommon to classify Japan as a German civil law country, particularly when focusing on Commercial and Company law. Similarly, the German code influenced the development of commercial law in Korea, especially through the Japanese occupation. During the early decades of the $20^{\text {th }}$ century, China (and hence Taiwan) examined European law in seeking to improve the operation of their commercial law. China introduced civil codes in 1925 and 1935 that, except for family and inheritance law, were shaped by German civil law. Of course, China has its own ancient legal tradition and also experienced Mao and the Cultural Revolution. The Scandinavian legal system was not spread to any country outside Northern Europe.

Critically, Merryman (1996) argues that the exportation of the Napoleonic Code had more pernicious implications in French, Belgian, Dutch, Spanish and Portuguese colonies than in France itself. According to this view, the adoption of the French civil code has crippled the judicial systems of many French legal origin colonies and hindered their ability to develop efficiently adaptive legal systems. There are four inter-related reasons.

First, the French rigidly imposed the Code Civil in its colonies even though there were and remain -- serious conflicts between the Code and local laws (ZK, 1998, p. 109-13). ${ }^{13}$ Tensions between local law and the transferred doctrine may impede the efficient development 
and application of the law with negative implications for financial development (Berkowitz, Pistor, and Richard, 2002).

Second, when the French instilled the Code, they brought the theory of the Napoleonic doctrine with its antagonism toward jurisprudence and its reliance on judicial formalism to minimize the role of judges. The French did not also bring the practical knowledge of how to circumvent some of the negative attributes of the Code and create an efficient role for judges (Merryman, 1996).

Third, given the Napoleonic doctrine, judges frequently "... are at the bottom of the scale of prestige among the legal professions in France and in many nations that adopted the French Revolutionary reforms, and the best people in those nations accordingly seek other legal careers" (Merryman, 1996, p. 116). Consequently, it is more difficult to develop efficiently responsive legal systems if the courts do not attract the best minds. Also, the static theory of the Napoleonic doctrine may become self-fulfilling: the best minds choose other professions, which hinders efficient legal flexibility. As a consequence, the legislature will have a tendency to write "bright line laws" to limit the role of the courts. As argued by Pistor et al. (2002, 2003), once a country adopts the "bright line" approach to law making, it is very difficult to change. Courts will not be challenged to develop legal procedures and methods to deal with emerging conditions. Thus, according to some scholars, these characteristics of the French law have worked to retard the development of efficiently adaptive legal systems that support financial development.

Fourth, France has a long history of avoiding open disputes about legal interpretation (Dawson, 1968). Moreover, Napoleonic doctrine formally inhibits open disputations by judges on how they weigh competing statutes, ambiguous laws, and past court decisions in deciding new cases. The exportation of this characteristic to French legal origin colonies, i.e., the absence of a legal culture of openly discussing the application of the law to evolving conditions, hindered the 
development of efficient legal systems around the world accordingly. From this perspective, French legal origin colonies imported a restrictive, formalistic legal doctrine under particular conditions that enhanced the probability that their legal systems would be less efficiently adaptable than Common and German civil law countries and even than the legal system in France itself.

\subsection{From Legal Origin to Finance: Political \& Adaptability Mechanisms}

We now describe two mechanisms through which legal origin may influence financial development. The political mechanism is based on two premises. First, legal traditions differ in the emphasis they place on protecting the rights of private investors relative to the rights of the State. Second, private property rights protection forms the foundation for financial development. Thus, historically determined differences in legal origin can help explain existing differences in financial development according to this component of the law and finance view (LLSV, 1998).

The political mechanism holds that the Civil law has tended to support the rights of the State, rather than private property rights, to a greater degree than the Common law with adverse implications for financial development. Indeed, La Porta, et al. (2003) find that in civil law countries, the State is less likely to grant judges tenure, give courts jurisdiction over cases involving the government, or permit judicial review of the constitutionality of laws.

LLSV (1999, p. 231-2) state that a civil legal tradition, then, can be taken as a proxy for the intent to build institutions to further the power of the State. A powerful State with a responsive civil law at its disposal will tend to divert the flow of society's resources toward favored ends, which is antithetical to competitive financial markets. Furthermore, a powerful State will have difficulty credibly committing to not interfere in financial markets, which will also hinder financial development. Thus, the law and finance theory holds that Civil law countries will have 
weaker property rights protection and lower levels of financial development than countries with other legal traditions.

In contrast, the Common law has historically tended to side with private property owners against the State. Rather than becoming a tool of the State, the Common law has acted as a powerful counterbalance that promotes private property rights. Rajan and Zingales (2003) note that governments in Civil Law countries were more effective than governments in Common Law countries in expanding the role of government at the cost of financial market development during the Interwar period 1919 - 1939. They attribute this to the stronger role of the judiciary vis-à-vis the legislature in Common Law countries. Thus, the law and finance theory holds that the British Common law supports financial development to a greater degree than the Civil law systems.

The second mechanism linking legal origin with financial development is the adaptability mechanism, which is built on two premises. First, legal systems differ in their ability to adjust to changing circumstances. Second, if a country's legal system adapts only slowly to changing circumstances, large gaps will open between the financial needs of an economy and the ability of the legal system to support those needs.

According to the adaptability channel, legal systems that embrace case law and judicial discretion tend to be more responsive to changing financial conditions than legal systems that adhere rigidly to formalistic procedures and that rely more strictly on judgments based narrowly on statutory law (Posner, 1973). Inefficient laws are challenged in the courts, so that the process of litigation and re-litigation improves the efficiency of the law (Pistor et al., 2002). In contrast, legal systems that reject jurisprudence necessarily rely more on statutory law changes to modernize and adapt the law. A large legal literature, however, argues that statutory law is slow and costly to change, so that the absence of jurisprudence tends to hinder the efficiency with which laws adapt to changing conditions (Bailey and Rubin, 1994). ${ }^{14}$ For example, in a legal system where judges 
do not got beyond the statutes, “... a corporate insider who finds a way not explicitly forbidden by the statutes to expropriate outside investors can proceed without fear of an adverse judicial ruling" (LLSV, 2000a, p. 9). If statutes are constantly playing “catch-up," this will hinder efficient corporate finance and financial development.

Thus, the adaptability channel predicts that French legal origin countries, albeit not necessarily France itself, have a lower probability of developing well-functioning financial systems than German civil law and especially Common law countries. The adaptability channel holds that the Common law is inherently dynamic as it responds case-by-case to the changing needs of society. This limits the opportunities for large gaps to grow between the demands of society and the law. Indeed, La Porta, et al. (2003) show that common law countries are more likely to admit judicial decisions as a source of law. In addition, Djankov, et al. (2003a) stress that differences in legal formalism also influence the adaptability of the law. They find that common law countries tend to have less legal formalism in terms of regulating the collection and presentation of evidence, requiring elaborate and extensive procedures throughout judicial processes, insisting on written documentation at every stage of the process, and setting rigid procedural requirements on communication between parties. In contrast, the Napoleonic doctrine's distrust of judges induces a reliance on judicial formalism. This hinders the flexibility of the legal system in many French law countries, with adverse implications on financial development. Furthermore, as noted, many legal scholars argue that the German law falls close to the Common law in terms of adaptability since it rejected the Napoleonic doctrine and instead maintained its historical roots in jurisprudence.

While the political and adaptability mechanism are inter-related parts of the law and finance theory and while they both predict that legal origin shapes financial development, they make conflicting predictions regarding French versus German civil law countries. The political 
channel holds that the Civil law tradition - both French and German - tends to centralize and intensify state power and therefore takes a more wary stance toward the development of free financial systems than the Common law. In contrast, the adaptability channel stresses that Common law and German civil law countries have notably more adaptable legal traditions than French civil law countries.

Second, the two mechanisms make different predictions concerning the channels through which legal systems influence the development of financial markets. The political mechanism contends that State control of the judiciary produces a system that focuses more on the power of the State and less on the private contracting rights of individual investors than a legal system characterized by an independent judiciary. Thus, the political channel stresses that cross-country differences in the independence of the judiciary are critical for explaining cross-country differences in financial development. In contrast, the adaptability mechanism stresses that crosscountry differences in the flexibility of the law are critical for explaining cross-country differences in financial development. ${ }^{15}$

One can overemphasize the difference between the political and adaptability channels, however. The political channel focuses on the power of the State while the adaptability channel highlights differences in the ability of legal systems to evolve with changing conditions.

Jurisprudence, however, may be much less likely in a system where the State controls the judiciary than in a system where the judiciary enjoys greater independence (Damaska, 1986; Glaeser and Shleifer, 2002).

\subsection{Skeptical Views regarding the Law and Finance Theory}

A number of criticisms have been levied at the law and finance theory ranging from skepticism about classifying countries by legal origin, to questions about whether legal origin is a fundamental determinant of financial development, to doubts about the central role of investor 
protection laws in promoting financial development. Although an influential strand of the law literature holds that the Common law evolves comparatively efficiently as jud ges respond case-bycase to unforeseen and changing conditions (Posner, 1973), this view is by no means unanimous. ${ }^{16}$ It is not necessarily the case that the case law responds more effectively than statutory changes. For instance, as exemplified by the law on contracts for the benefit of third parties, English law has clung with remarkable tenacity to the principle that "only a person who is a party to a contract can sue on it." (ZK. 1998, p. 468) In contrast, the Continental countries granted greater rights to third parties through statutory changes. Furthermore, Lamoreaux and Rosenthal (2002) provide a fascinating comparison of the laws of incorporation and partnerships in the United States and France. They argue that the French civil law system responded more effectively to evolving economic conditions than the U.S common law system.

Furthermore, many question whether it is appropriate and analytically useful to categorize countries as simply having British, French, German, or Scandinavian legal origins. As stressed above, Dawson $(1960,1968)$ and Merryman $(1985,1996)$ stress than when the French legal system was exported to colonies around the world, it operated less effectively than in France itself. One may further refine the categorization of legal systems. For instance, Franks and Sussman (1999) describe differences in the adaptability of two Common law countries: the United Kingdom and the United States. Also, legal scholars study differences across the French civil law countries of Latin America. Along the same lines, Berkowitz, Pistor, and Richard (2002) stress that the manner in which national legal systems were initially transplanted and received, e.g., through conquest, colonization, or imitation, around the world is very important for economic development. They stress that the transplant process - not just whether countries are classified as having British, French, German, or Scandinavian legal origins - is important for establishing wellfunctioning legal systems. Thus, many observers question the usefulness of using legal origin to 
explain property rights protection, the efficient adaptability of legal systems, and hence financial development.

Some researchers question the role of legal heritage in shaping legal and financial institutions and instead stress that politics determines the degree of investor protection laws, the energy devoted to private contract enforcement, the extent to which legal systems emphasize the rights of property owners relative to the rights of the State, and hence the development of competitive financial markets (Pound, 1991; Roe, 1994; Pagano and Volpin, 2001; Rajan and Zingales, 2003; Haber, et al., 2003). From this perspective, those in power shape policies and institutions - including legal and financial institutions - to stay in power and enrich themselves. The elite may or may not favor financial development, which ultimately influences the operation of legal and financial institutions. This view does not reject the importance of legal institutions in shaping financial systems. Rather, it stresses the political roots of differences in legal and financial institutions. $^{17}$

Skepticism about the central role of legal institutions in shaping financial development also emanates from those highlighting culture. Stulz and Williamson (2003) note that different religions have different attitudes toward the rights of creditors. In particular, the Catholic Church has historically taken a negative stance toward the charging of interest and creditor rights. Similarly, the Qur'an prohibits the charging of interest, so that some countries still impose this prohibition. In contrast, according to this culture-religion view, the Reformation advanced a different religious attitude towards finance, whereby the payment of interest was considered a normal part of commerce, so that the rights of creditors were more naturally emphasized in countries dominated by Protestant religions. From this perspective, countries with a predominantly Catholic religious heritage would tend to have less developed credit markets and more poorly developed loan issuing financial institutions. 
An additional line of attack comes from geography. The endowment view stresses that differences in geography and disease have critically shaped patterns of political, institutional, and economic development (Diamond 1997; Jones 1981; McNeill 1963; Crosby 1989; Engerman and Sokoloff 1997, 2002; Sokoloff and Engerman, 2000; Acemoglu, Johnson, and Robinson, 2001, 2002).

Acemoglu, Johnson, and Robinson (2001, henceforth AJR) base their theory of how endowments influence enduring institutions on three premises. First, AJR note that Europeans adopted different types of colonization strategies. At one end of the spectrum, the Europeans settled and created institutions to support private property and check the power of the State. These "settler colonies" include the United States, Australia, and New Zealand. At the other end of the spectrum, Europeans sought to extract as much from the colony as possible. In these "extractive states," Europeans did not create institutions to support private property rights; rather, they established institutions that empowered the elite to extract gold, silver, etc. (e.g., Congo, Ivory Coast, and much of Latin America). Second, AJR's theory holds that the type of colonization strategy was heavily influenced by the feasibility of settlement. In inhospitable environments, Europeans tended to create extractive states (AJR, 2001). In areas where endowments favored settlement, Europeans tended to form settler colonies. The final piece of the AJR theory of institutional development stresses that the institutions created by European colonizers endured after independence. Settler colonies tended to produce post-colonial governments that were more democratic and more devoted to defending private property rights than extractive colonies. In contrast, since extractive colonies had already constructed institutions for effectively extracting resources, the post-colonial elite frequently assumed power and readily exploited the pre-existing extractive institutions. AJR (2001, 2002), Beck, Demirguc-Kunt, and Levine (2003a, henceforth 
BDL), and Easterly and Levine (2003) provide empirical support for the view that endowments influence institutions, including financial institutions.

Other work questions the central role of investor protection laws in shaping the efficient flow of capital to corporations and overall financial development. For instance, Dyck and Zingales (2003) find that non-traditional corporate control mechanisms, such as an open, competitive media and a high degree of product market competition, are as important as statutory protection of minority shareholders in explaining the private benefits of controlling a corporation. Furthermore, Guiso, et al. (2000) hold that "social capital" the informal rules that govern social interactions play a critical role in determining financial development in Italy. Similarly, Franks, et al (2003) argue that implicit contracts enforced by informal mechanisms fostered small shareholder participation in financial markets in late $19^{\text {th }}$ and early $20^{\text {th }}$ century England. Johnson, McMillan, and Woodruff (2002a), however, note that while informal, relational contracting has been important in post-communist countries and can sustain old relationships, effective formal court systems are crucial in fostering new commercial relationships and boosting the overall level of trust in society.

\section{EMPIRICAL EVIDENCE ON LAW AND FINANCE}

In this section, we review the empirical evidence on the law and finance view. The first sub-section discusses evidence on the links between legal origin and financial development, investor protection laws, and private property rights protection. Next, we assess whether investor protection laws influence corporate valuations, corporate governance, and the operation of financial markets? The third subsection reviews emerging evidence on the mechanisms -- the political and adaptability mechanisms - linking the law to financial development. 


\subsection{Legal Origin and Financial Development}

To measure legal origin, many researchers follow LLSV (1998) in classifying a country as having either a British common law, French civil law, German civil law, or Scandinavian civil law based on the source of each country's Company or Commercial code. David and Brierley (1985) argue that commercial legal systems of most countries derive from these four major legal families. Reynolds and Flores (1989) provide information on the origins of national laws for over 100 countries. Using these legal origin dummy variables, researchers have initiated an energetic examination of the relationship between legal and financial institutions.

LLSV $(1997,1998)$ find that French civil law countries have the lowest levels of financial development even after controlling for the overall level of economic development. French civil law countries have smaller stock markets (as measured by market capitalization divided by GDP), less active initial public offering markets, and lower levels of bank credit as a share of GDP. These results are broadly consistent with the theories of law and finance discussed above. ${ }^{18}$

Empirical work also examines the connection between legal origin and specific laws governing the rights of external investors in firms. To the extent that the legal system protects shareholders and creditors, this may tend to (1) foster better functioning stock and debt markets and (2) facilitate the flow of capital to firms.

Consider LLSV's (1998) Shareholder rights measure, which equals an index aggregating the following six measures. The index is created by adding 1 when (a) the country allows shareholders to mail their proxy vote to the firms, (b) shareholders are not required to deposit their shares prior to the General Shareholders Meeting, (c) cumulative voting or proportional representation of minorities on the board of directors is allowed, (d) an oppressed minorities mechanism is in place, (e) the minimum percentage of share capital that entitles a shareholder to call for an Extraordinary Shareholders Meeting is less than the sample median (10 percent), or (f) 
shareholders have preemptive rights that can only be waived by a shareholders vote. Higher values indicate greater minority shareholder rights such that majority shareholders have less discretion in exploiting minority shareholders.

LLSV (1998) show that French civil law countries have lower levels of Shareholder Rights. LLSV (1997) and Levine (2003) go on to show that low levels of Shareholder Rights are associated with poorly developed equity markets. In contrast, Common law countries have high levels of Shareholder Rights with correspondingly high levels of equity market development. Furthermore, LLS (2003) find laws and regulations that force information disclosure and that foster private enforcement through strict liability rules enhance market development. Moreover, LLS (2003) show that French legal origin countries tend to have relatively weak liability rules and weak information disclosure requirements, such that the legal and regulatory environment in French civil law countries tends to emphasize private contract enforcement less effectively than in Common law countries.

Next, consider Creditor Rights, which is an index that is formed by adding one when (a) the country imposes restrictions, such as creditors consent or minimum dividends, to file for reorganization, (b) secured creditors are able to gain possession of their security once the reorganization petition has been approved (no automatic stay on assets), (c) secured creditors are ranked first in the distribution of the proceeds that result from the disposition of the assets of a bankrupt firm, and (d) the debtor does not retain the administration of its property pending the resolution of the reorganization. Higher values indicate greater creditor rights.

As shown by LLSV (1998), countries with a Common law tradition tend to have greater Creditor Rights than French civil law countries. Furthermore, LLSV (1997) and Levine (1998, 1999) show that greater Creditor Rights are positively associated with financial intermediary development. 
Furthermore, Levine $(1998,1999)$ and Levine, Loayza, and Beck (2000) empirically trace the chain of connections from legal origin to financial development to economic growth. Specifically, legal origin importantly accounts for cross-country differences in the development of bank and stock markets and these differences in financial development explain international differences in long-run rates of economic growth. Thus, a growing body of work suggests that legal institutions influence the operation of financial institutions with substantial implications for corporate finance and investment decisions, along with the overall rate of economic growth.

Nevertheless, legal origin is certainly not the whole story. Rajan and Zingales (2003) argue that financial development does not always evolve monotonically over time and that cross-country differences in financial development also change materially over time. Thus, time-invariant factors such as legal origin cannot fully explain time-variation in the relative levels of financial development across countries. Rajan and Zingales (2003) stress the important role of political forces in shaping policies toward financial markets and intermediaries and hence the development of financial systems. Pistor, et al. (2002, 2003) disagree with Rajan and Zingales (2003) in the area of corporate law and argue that even acute political changes in Germany, France, and England during the $20^{\text {th }}$ century did not substantively alter the evolution of corporate law.

While recognizing the limitations of the law and finance theory's ability to explain intertemporal changes in relative levels of financial development across countries, recent research has conducted a number of robustness checks regarding the linkages between legal origin and financial development. Levine, (1998, 1999, 2003a), Levine, Loayza, and Beck (2000), and BDL (2003a) use different measures of financial development and also expand the set of countries to over 100. This research confirms that legal origin helps explain cross-country differences in financial development. In particular, French civil law countries, though not France itself, tend to have particularly low levels of equity market development. To the extent that competitive 
securities markets rely more on legal institutions than banks, these results are very consistent with theories that suggest a strong link between legal institutions and financial development.

Furthermore, BDL (2003a) show that French civil law countries tend to have lower levels of private property rights protection. Again, this is consistent with the view that French legal origin countries place comparatively less emphasis on the rights of private property holders than countries with Common or German civil law tradition.

While still in its nascent stages, research is also running statistical horse races between theories that stress the role of legal institutions and alternative theories. As noted earlier, an influential body of works stresses the dominating role of political forces in shaping financial development. While it is extraordinarily difficult to measure cross-country differences in political institutions, BDL (2003a) make an initial attempt to control for differences in political systems in assessing the law and finance relationship. They include measures of the degree of competitive and executive elections, measures of the number of influential veto players in legislative process, and an overall index of national openness based on trade openness. BDL (2003a) continue to find that legal origin explains differences in equity market development, banking sector development, and the level of private property rights protection even when controlling for these proxies for characteristics of the political environment.

BDL (2003a) also control for natural resource endowments and religion in examining the robustness of the connection between legal heritage and financial development. To control for religion, BDL (2003a) measure the percentage of the population adhering to different religious faiths. To proxy for natural resource endowments, BDL (2003a) use the AJR measures of settler mortality. As a further check, they use measures of each country's latitude (the absolute value of either the geographic mean of the country or of the country's capital city) as an exogenous proxy for the degree to which the country is in a tropic environment. They find that endowments 
importantly explain cross-country differences in financial institutions, confirming the AJR and Engerman and Sokoloff (1997) theories of institutional development. Nevertheless, legal origin continues to explain property rights differences and stock market development even when controlling for endowments.

Similarly, Stulz and Williamson (2003) examine the impact of legal origin on financial development while controlling for cross-country differences in culture, as measured by the dominant religion in each country. They find that legal origin is more important than religion in explaining laws protecting equity holders, while religious differences are more closely tied to laws protecting creditors. Thus, while culture matters, legal origin still explains cross-country differences in financial development, especially equity market development, after controlling for differences in religious heritage.

\subsection{Investor Protection Laws, Corporate Finance, and Financial Development}

We now examine the empirical evidence concerned with the relationship between investor protection laws and the corporate financing decisions of firms and the operation of financial markets. This subsection discusses this more microeconomic-based work.

Recent work suggests that legal institutions influence the valuation of firms and banks and hence the cost of capital. Claessens, et al., (2002), LLSV (2002), and Caprio, et al, (2003) find that stronger investor protection laws, as measured by higher values of the Shareholder Rights indicator defined above, tend to enhance corporate valuations. Furthermore, LLSV (2000b) show that countries with strong Shareholder Rights are able to force firms to disgorge cash and pay higher dividends. This evidence is consistent with the view that investor protection laws influence corporate governance with measurable implications on stock prices and dividend policies. In related work Johnson, McMillan, and Woodruff (2002b) show that countries with strong private 
property rights protection tend to have firms the reinvest their profits, but where property rights are relatively weakly enforced, entrepreneurs are less inclined to invest retained earnings.

Empirical analyses also find a strong connection between investor protection laws and both ownership concentration and the private benefits of corporate control. The data are consistent with the view that stronger legal protection of investor rights makes minority investors more confident about their investments, which reduces the need for firms (Claessens, et al., 2000; LLS, 1999) and banks (Caprio, et al., 2003) to use concentrated ownership as a mechanism for alleviating corporate governance problems. Furthermore, Dyck and Zingales (2003) and Zingales (1994) show that greater statutory protection of minority shareholder rights and more effective legal enforcement of those rights lowers the private benefits of controlling a corporation.

Legal institutions also influence the ability of firms to raise capital. Thus, laws may influence the degree to which firms operate at financially constrained levels. Kumar, Rajan, and Zingales (2001) and Beck, Demirguc-Kunt and Maksimovic (2002) find that countries with legal institutions that more effectively protect property rights tend to have larger firms. This is consistent with the law and finance theory that in countries with better legal institutions, firms are less constrained by retained earnings and operate at more efficient scales.

Recent work has also drawn a connection between legal institutions and the efficiency of equity markets. Morck, Yeung, and Yu (2000) examine the relationship between legal institutions, the availability and precision of information on firms, and the efficiency of stock prices. They find that the degree to which legal institutions protect private property rights and the rights of minority shareholders help account for cross-country differences in stock market synchronicity. That is, in countries where legal institutions do not protect shareholders effectively, domestic stock prices move together, so there is less information in individual stock prices. 
The impact of legal institutions on corporate finance may also play a role in explaining the Asian financial crisis. Johnson, Boone, Breach, and Friedman (2000) show that weak legal institutions - legal institutions that do not effectively support the claims of outside investors - help account for cross-country differences in stock market declines and exchange rate depreciations during the Asian crisis. Specifically, if managers expropriate more firm assets as expected rates of return on firm investment fall, then adverse shocks to the economy will lead to greater expropriation, larger stock declines, and bigger incipient capital outflows in countries with weak legal institutions. Johnson, Boone, Breach, and Friedman (2000) find evidence consistent with this legal institution explanation of exchange rate and stock price declines.

Wurgler (2000) and Beck and Levine (2002) examine whether legal institutions influence the allocation of capital across firms and industries. They show that legal institutions influence the efficiency with which financial systems re-allocate capital across industries. Specifically, countries with legal institutions that define and enforce strong rights for small, outside investors more effectively reallocate the flow of finance toward growing firms and away from declining firms. Thus, well-functioning legal systems boost the efficiency with which financial systems allocate capital.

Also, Demirguc-Kunt and Maksimovic (1998) show that countries with legal institutions that protect outside investors tend to create better functioning financial systems that fund faster growing firms. Claessens and Laeven (2003) show that legal rules regarding investor protection influence the types of firms that get financed. Specifically, in countries with strong investor protection laws, firms with less collateral have an easier time getting external finance than similar firms in countries with poorly functioning legal institutions. Furthermore, building on Rajan and Zingales (1998), Beck and Levine (2002) show that the efficiency of legal institutions increases the availability of financing to industries and the creation of new establishments. Along these 
lines, Demirguc-Kunt and Levine (2001), Beck and Levine (2002), Demirguc-Kunt and Maksimovic (2002), and Levine (2002) provide empirical support for the view advanced by LLSV (2000a) that the legal approach is a more fruitful way to explain corporate performance than the more conventional distinction between bank-based and market-based financial systems. Thus, national legal institutions are critically important in determining the supply of capital available for corporate investment.

Some careful case-studies, however, challenge the importance of investor protection laws. For example, Franks et al. (2003) trace the history of investor protection laws and corporate ownership in the United Kingdom. They note that in a landmark court case, Foss v. Harbottle (1843), the judge found that no individual shareholder could sustain an action against the company, thereby rejecting the notion of mi nority investor protection. Not until 1948 did Parliament begin to enact limited legislation to protect minority shareholders and Franks, et al. (2003) stress that it was not until 1980 that Parliament enacted strong minority shareholder rights statutes. According to the law and finance view, the U.K. should have had comparatively inactive equity markets and concentrated ownership in the $19^{\text {th }}$ and early $20^{\text {th }}$ centuries and then had more dispersed ownership and greater equity market activity after 1948 and especially after 1980. The evidence is, however, is at best mixed. Ownership concentration was similar in 1900 and 1960, which is not consistent with the law and finance prediction, but market liquidity did jump substantially with enactment of stronger shareholder rights legislation.

Similarly, Aganin and Volpin (2003) argue that the history of investor protection laws and corporate ownership in Italy during the twentieth century do not provide strong support for the law and finance view. They hold that investor protection laws were weak at the beginning of the century, did not change much after World War II, but were strengthened after 1974 and especially after 1990. They note that the law and finance theory predicts a fall in corporate ownership 
concentration after 1974 as stronger investor protection laws make small shareholder more confident about their investments. But, corporate ownership concentration did not fall after 1974; it rose, and ownership concentration was more diffuse at the beginning of the $20^{\text {th }}$ century than at the start of the $21^{\text {st }}$ century. Aganin and Volpin (2003), therefore, question the applicability of the law and finance view in Italy and stress the importance of considering politics in explaining corporate ownership and the evolution of investor protection laws.

\subsection{Law and Finance Theory's Political and Adaptability Mechanisms}

While an exploding body of research examines (a) the links between legal origin and investor protection and financial development and (b) the links between investor protection laws and corporate financing efficiency, researchers are only beginning to examine the mechanisms through which legal origin operates. The political channel postulates that legal traditions differ in terms of the priority they give to private property rights relative to the rights of the state. The adaptability channel stresses that legal traditions differ in terms of their responsiveness to changing socioeconomic conditions.

BDL $(2003 \mathrm{~b}, \mathrm{c})$ study whether legal origin influences financial development primarily through the political or adaptability mechanism by exploiting the data assembled by Djankov et al. (2003a) and La Porta, Lopez-de-Silanes, Pop-Eleches, and Shleifer. (2003). To proxy for the political channel, Supreme Court Power is a dummy variable that takes on the value one if Supreme Court Judges have both life-long tenure and power over administrative cases, and zero otherwise. The political channel predicts that (i) Civil law countries are less likely to grant Supreme Court Power and (ii) Supreme Court Power will be positively associated with private property rights protection and financial development. To proxy for the adaptability channel, Case Law is a dummy variable that indicates whether judicial decisions are a source of law. The adaptability channel predicts that (a) Common law and German civil law countries are more likely 
to admit judicial decisions as a source of law than French law countries and (b) countries in which judicial decisions are a source of law will adapt more efficiently to changing financial conditions.

BDL (2003b) find that, French and German civil law countries have significantly less

Supreme Court Power than British common law countries. This is consistent with the view that the State grants less independence in a civil law tradition than in a common law system. The results also indicate that French civil law countries have significantly less Case Law -- i.e., a significantly smaller role for judicial decisions as a source of law - than in German civil law or British common law. This is consistent with the view that German civil and British common legal traditions rely more on jurisprudence than French c ivil law systems.

BDL (2003b) next examine whether the proxy for the political channel or the proxy for the adaptability channel is better able to account for international differences in stock market, financial intermediary, and private property rights development. They use two-stage least squares, where the instrumental variables are legal origin dummy variables.

The results provide support for the adaptability channel but not the political channel. Specifically, the political channel predicts that Supreme Court Power will enter positively: less State control of the courts will translate into greater financial development. In contrast, however, Supreme Court Power enters either insignificantly, or negatively. Instead, the data are consistent with the adaptability channel: Case Law is positively associated with stock market development, bank development, and private property rights protection.

Research also focuses on judicial formalism, which is related to the adaptability mechanism. Excessive formalism may slow legal processes, increase legal costs, and hinder the ability of courts to arrive at fair judgments due to the rigid adherence to bright-line-rules (Johnson et al., 2000; Djankov et al., 2003a; Glaeser and Shleifer, 2002). Indeed, Djankov, et al. (2003a) construct an index of legal formalism that measures the need for legal professionals, written 
documents, statutory justification, the statutory codification of evidence, and the formal procedural steps associated with legal processes. They find that legal formalism is lower in common law countries and that less legal formalism is associated with shorter proceedings and less corruption.

In terms of finance, Acemoglu and Johnson (2003) examine the impact of legal formalism on financial development using legal origin as an instrumental variable. Although legal formalism is not linked with banking sector development, they find that the exogenous component of legal formalism is associated with stock market development. Greater legal formalism lowers stock market development, which is consistent with the adaptability mechanism.

\section{Conclusions.}

A rapidly growing body of research examines the role of legal institutions in explaining financial development. The law and finance theory holds that (i) historically determined differences in legal tradition influence national approaches to private property rights protection, the support of private contractual arrangements, and the enactment and enforcement of investor protection laws and (ii) these resultant legal institutions shape the willingness of savers to invest in firms, the effectiveness of corporate governance, and the degree of financial market development. Each of the components of the law and finance theory is being dissected, critiqued, and evaluated from a broad array of perspectives. Many economists, legal scholars, political scientists, and historians are questioning, testing and modifying the law and finance theory. This promises to be an exciting and important area of inquiry in coming years. 


\section{References}

Acemoglu, D., Johnson, S., 2003. Unbundling institutions: Law versus politics. unpublished MIT mimeo.

Acemoglu, D., Johnson, S., Robinson, J. A., 2001. The colonial origins of comparative development: an empirical investigation. American Economic Review 91, 1369-1401.

Acemoglu, D., Johnson, S., Robinson, J. A., 2002. Reversal of fortunes: geography and institutions in the making of the modern world income distribution. Quarterly Journal of Economics 117, 1133-1192.

Aganin, A., Volpin, P., 2003. History of corporate ownership in Italy. London Business School mimeo.

Bailey, M. J., Rubin, P. H., 1994. A positive theory of legal change. International Review of Law and Economics 14, 467-477, December 1994.

Barth, J., Caprio, G., R. Levine. 2003. Bank Supervision and Regulation: What Works Best? Journal of Financial Intermediation, forthcoming.

Beck, T., A. Demirgüç-Kunt and R. Levine. 2003c. Legal obstacles to external finance. University of Minnesota mimeo.

Beck, T., Demirgüç-Kunt, A., Levine, R., 2003b. Law and finance. Why does legal origin matter? Journal of Comparative Economics, forthcoming.

Beck, Thorsten, Demirgüç-Kunt, Asli, and Levine, Ross, 2003a. Law, endowments, and finance. Journal of Financial Economics, forthcoming, 2003.

Beck, T., Demirgüç-Kunt, A., Levine, R., 2001. Legal theories of financial development. Oxford Review of Economic Policy 17, 483-501.

Beck, T., Demirgüç-Kunt, A., Maksimovic, V., 2002. Financial and legal institutions and firm size. Unpublished working paper, World Bank.

Beck, T., Levine, R., 2002, Industry growth and capital allocation: does having a market- or bankbased system matter. Journal of Financial Economics 64, 147-180.

Beck, T., Levine, R., 2003. Stock markets, banks, and growth: panel evidence, Journal of Banking and Finance, forthcoming.

Beck, T., Levine, R., Loayza, N., 2000. Finance and the sources of growth. Journal of Financial Economics 58, 261-300. 
Berkowitz, D., Pistor, K., Richard; J. F., 2002, Economic development, legality, and the transplant effect. European Economic Review, 47,165-195.

Blume, Lawrence E., Rubinfeld, Daniel L., 1982. The dynamics of the legal process. Journal of Legal Studies 11, 405-419.

Caprio, G., Laeven, L., Levine, R., 2003. Governance and bank valuation. University of Minnesota, mimeo.

Claessens, C., Laeven, L., 2003. Financial development, property rights, and growth. Journal of Finance, forthcoming.

Claessens, S., Djankov., Fan, J., Lang, L. 2002. Expropriation of minority shareholders in East Asia. Journal of Finance 57.

Claessens, S., Djankov, S., Lang, L. H.P., 2000. The separation of ownership and control in East Asian corporations. Journal of Financial Economics, 58, 81-112.

Coase, R., 1960. The problem of social cost. Journal of Law and Economics 3, 1-44.

Coke, E., 1628 [1979 version]. The First Part of the Institutes of the Laws of England. Garland Publishing, Inc., New York, NY.

Coffee, J.C., 2001. Do norms matter? A cross-country examination of the private benefits of control. Unpublished working paper 183, Columbia Law School, New York, 2001.

Coffee, J.C., 2000. "Privatization and corporate governance: The lessons from securities market failure." Unpublished working paper 158. Columbia Law School, New York.

Cooter, R., Kornhauser, L., 1980. Can litigation improve the law without the help of judges? Journal of Legal Studies 9, 139-63.

Cooter, Robert, Kornhauser, Lewis, and Lane, D., 1979. "Liability Rules, Limited Information and the Role of Precedent." Bell Journal of Economics 10, 366-81.

Crosby, A. W., 1989. Ecological Imperialism: The Biological Expansion of Europe, 900-1900. Cambridge University Press, Cambridge.

Damaska, Mirjan R., 1986. The Faces of Justice and State Authority: A Comparative Approach to the Legal Process, New Haven, CT: Yale University Press.

David. R., and Brierley, J., 1985. Major Legal Systems in the World Today. Stevens and Sons: London.

Dawson, J. P., 1960. A History of Lay Judges. Harvard University Press, Cambridge, MA.

Dawson, J. P., 1968. The Oracles of the Law. University of Michigan Law School, Ann Arbor, MI 
(Reprinted in 1986 by William S. Hein \& Co., Inc. Buffalo, New York).

Demirgüç-Kunt, A., and Levine, R. 2001. Financial Structure and Economic Growth: A CrossCountry Comparison of Banks, Markets, and Development. Cambridge, MA: MIT Press.

Demirgüç-Kunt, A., Maksimovic, V., 1998. Law, finance, and firm growth. Journal of Finance 53, 2107-2137.

Demirgüç-Kunt, A., Maksimovic, V., 2002. Funding growth in bank-based and market-based financial systems: Evidence from firm level data. Journal of Financial Economics 65, 337-363.

Diamond, J, 1997. Guns, Germs, and Steel: The fates of Human Societies. W.W. Norton, New York.

Djankov, S., Glaeser, E., La Porta, R., Lopez-de-Silanes, F., Shleifer, A., 2003b. The New Comparative Economics. Journal of Comparative Economics 31, forthcoming.

Djankov, S., La Porta, R., Lopez-de-Silanes, F., Shleifer, A., 2003a. Courts. Quarterly Journal of Economics 118, 457-522.

Dyck, A., Zingales, L., 2003. Private benefits of control: An international comparison. Journal of Finance, forthcoming.

Easterbrook, R., Fischel, D., 1991. The economic structure of corporate law. Cambridge, MA: Harvard University Press.

Easterly, W. Levine, R., 1997. Africa's growth tragedy: policies and ethnic divisions. Quarterly Journal of Economics 112, 1203-1250.

Easterly, W. Levine, R., 2003. Tropics, germs, and crops. Journal of Monetary Economics, 50, 339.

Engerman, S., Sokoloff, K., 1997. Factor endowments, institutions, and differential paths of growth among new world economies. In Haber, S.H. (Ed.). How Latin America Fell Behind. Stanford University Press, Stanford CA, 260-304.

Engerman, S., Sokoloff, K., 2002. Factor Endowments, Inequality, and Paths of Development Among New World Economies. National Bureau of Economic Research Working Paper \#9259.

Ertman, T., 1997. Birth of the Leviathan. Cambridge University Press, Cambridge, UK.

Finer, S., 1997. The History of Government. Vol. I-III. Cambridge University Press, Cambridge, UK.

Franks, J., Mayer, C., Rossi, S., 2003. The origination and evolution of ownership and control. Oxford Financial Research Centre Working Paper No. 1003-FE-01. 
Franks, J., Sussman, O., 1999. Financial innovations and corporate insolvency. Unpublished working paper. London Business School.

Glaeser, E., Johnson, S., Shleifer, A., 2001. Coase versus the coasians. Quarterly Journal of Economics 116, 853-899.

Glaeser, E., Shleifer, A., 2003. The Rise of the Regulatory State. Journal of Economic Literature $41,401-425$.

Glaeser, E., Shleifer, A., 2002. Legal origins. Quarterly Journal of Economics 117, 1193-1230.

Glendon, M.A., Gordon, M. W., Osakwe, C., 1982. Comparative Legal Tradition in a Nutshell. West Publishing Co., St. Paul, MN.

Guiso, L., Sapienza, P., Zingales, L., 2000. The role of social capital in financial development. National Bureau of Economic Research Working Paper, No. 7563.

Haber, S. H., Razo, A., Maurer, N., 2003. The Politics of Property Rights: Political Instability, Credible Commitments, and Economic Growth in Mexico, Cambridge, UK: Cambridge University Press.

Hart, O., 1995. Firms, Contracts, and Financial Structure. Oxford University Press: London.

Hayek, F., 1960. The Constitution of Liberty. The University of Chicago Press, Chicago, IL.

Jensen, M., Meckling, W., 1976. Theory of the firm: Managerial behavior, agency costs, and ownership structure. Journal of Financial Economic 3, 305-360.

Johnson, S., Boone, P., Breach, A., Friedman, E., 2000. Corporate governance in the Asian financial crisis, Journal of Financial Economics 58, 141-186.

Johnson, S., McMillan, J., Woodruff, C., 2002a. Courts and relational contracts. Journal of Law, Economics, and Organization 18, 221-277.

Johnson, S., McMillan, J., Woodruff, C., 2002b. Property rights and finance. American Economic Review 92, 1335-56.

Johnson, S., La Porta, R., Lopez-de-Silanes, F., Shleifer, A. 2000. Tunneling. American Economic Review Papers and Proceedings 90, 22-27.

Jones, E.L. 1981. The European Miracle: Environments, Economies, and Geopolitics in the History of Europe and Asia. Cambridge University Press, Cambridge, MA.

Kaplow, L., 1992. Rules versus Standards: An Economic Analysis. Duke Law Journal 42, 557629.

King, R. G., Levine, R., 1993a, Finance and growth: Schumpeter might be right, Quarterly Journal 
of Economics 108, 717-38.

King, R. G., Levine, R., 1993b. Finance, entrepreneurship, and growth: theory and evidence. Journal of Monetary Economics 32, 513-42.

Kumar, K., Rajan, R., Zingales, L., 2001. What determines firm size? Unpublished working paper, University of Chicago.

Lamoreaux, N. and Rosenthal, J-L. 2002. Organizational choice and economic development: a comparison of France and the United States during the mid- $19^{\text {th }}$ century. University of California at Los Angeles mimeo.

La Porta, R., Lopez-de-Silanes, F., Pop-Eleches, C., Shleifer, A., 2003. Judicial checks and balances. National Bureau of Economic Research Working Paper 9775.

La Porta, R., Lopez-de-Silanes, F., Shleifer, A., 2003. What works in securities laws? Harvard University mimeo.

La Porta, R., Lopez-de-Silanes, F., Shleifer, A., Vishny, R.W., 2002. Investor protection and corporate valuation, Journal of Finance 57, 1147-1170.

La Porta, R., Lopez-de-Silanes, F., Shleifer, A., Vishny, R.W., 2000b. Agency problems and dividend policies around the world. Journal of Finance 55, 1-33.

La Porta, R., Lopez-de-Silanes, F., Shleifer, A., Vishny, R.W., 2000a. Investor protection and corporate governance. Journal of Financial Economics 58, 3-27.

La Porta, R., Lopez-de-Silanes, F., Shleifer, A., Vishny, R.W., 1999. The Quality of Government. Journal of Law and Economic Organization 15, 222-279.

La Porta, R., Lopez-de-Silanes, F., Shleifer, A., Vishny, R.W., 1998. Law and finance. Journal of Political Economy 106, 1113-1155

La Porta, R., Lopez-de-Silanes, F., Shleifer, A., Vishny, R.W., 1997. Legal determinants of external finance. Journal of Finance 52, 1131-1150.

Levine, R., 1997. Financial development and economic growth: views and agenda, Journal of Economic Literature 35, 688-726.

Levine, R., 1998. The legal environment, banks, and long-run economic growth. Journal of Money, Credit, and Banking 30, 596-620.

Levine, R., 1999. Law, finance, and economic growth. Journal of Financial Intermediation 8, 3667.

Levine, R., 2003. Bank-based or market-based financial systems: which is better? Journal of Financial Intermediation 11, 398-428. 
Levine, R., 2003. Napoleon, bourses, and growth: with a focus on Latin America, in: Omar A., Cadwell, C. (eds.) Market Augmenting Government: Essays in Honor of Mancur Olson, Eds. University of Michigan Press, Ann Arbor, MI.

Levine, R., 2004. Finance and Growth: Theory, Evidence, and Mechanisms. Handbook of Economic Growth. Eds. P. Aghion and S. Durlauf, Amsterdam: North-Holland Elsevier Publishers, forthcoming.

Levine, R., Loayza, N., Beck, T., 2000. Financial intermediation and growth: causality and causes. Journal of Monetary Economics 46, 31-77.

Levine, R., Zervos, S., 1998. Stock markets banks and economic growth. American Economic Review 88, 537-58

Littleton, T., 1481 [1903 version] Littleton's Tenures in English. Eugene Wambaugh, (Ed.) John Bryne \& Co., Washington, D.C.

Macey, J.R., Miller, G.P., 1993. Corporate stakeholders: A contractual perspective. University of Toronto Law Journal 43, 401-427.

Mahoney, P., 2001. The Common law and economic growth: Hayek might be right. Journal of Legal Studies 30, 503-525.

McNeill, W. H. 1963. The Rise of the West: A History of the Human Community. University of Chicago Press, Chicago, IL.

Merryman, J.H., 1985. The Civil Law Tradition: An Introduction to the Legal Systems of Western Europe and Latin America. Stanford University Press, Stanford, CA.

Merryman, J. H., 1996. The French Deviation. The American Journal of Comparative Law 44, 109-119.

Modigliani, F., Miller, M., 1958. The cost of capital, corporation finance, and the theory of investment. American Economic Review 48, 261-297.

Morck, R., Yeung, B., Yu, W., 2000. The information content of stock markets: why do emerging markets have synchronous stock price movements. Journal of Financial Economics 58, 215-260.

North, D., 1981. Structure and Change in Economic History. Cambridge, MA: W.W. Norton and Company.

North, D., 1990. Institutions, Institutional Change, and Economic Performance. Cambridge University Press, Cambridge, UK.

Olson, M., 1993. Dictatorship, democracy, and development. American Political Science Review 87, 567-576. 
Pagano, M., and Volpin, P., 2001. The Political Economy of Finance. Oxford Review of Economic Policy 17, 502-519.

Pistor, K., Keinan, Y., Kleinheisterkamp, J., West, M.D., 2002. The evolution of corporate law. University of Pennsylvania Journal of International Economics and Law 23, 791-871.

Pistor, K., Keinan, Y., Kleinheisterkamp, J., West, M.D., 2003. Innovation in corporate law. Journal of Comparative Economics 31, forthcoming.

Pistor, K., Xu, C., 2002. Law enforcement under incomplete law: Theory and evidence from financial market regulation. London School of Economics Working Paper No. TE/02/442.

Priest, G. L., 1977. The Common Law Process and the Selection of Efficient Rules. Journal of Legal Studies 6, 65-82.

Posner, R.A., 1973. Economic Analysis of the Law. Boston, MA: Little-Brown, 1973.

Pound, J., 1991. Proxy voting and the SEC. Journal of Financial Economics 29, 241-285.

Rajan, R.G., Zingales, L., 1998. Financial dependence and growth. American Economic Review $88,559-586$.

Rajan, R.G., Zingales, L., 2003. The great reversals: the politics of financial development in the $20^{\text {th }}$ century. Journal of Financial Economics, 69, 2003.

Reynolds, T. and Flores, A., 1989. Foreign Law: Current Sources of Basic Legislation in Jurisdictions of the World. Rothman and Co., Littleton, Colorado.

Roe, M. J., 1994. Strong Managers Weak Owners: The Political Roots of American Corporate Finance. Princeton University Press, Princeton.

Rubin, Paul H., 1977. Why is the common law efficient? Journal of Legal Studies 6, 51-64.

Rubin, Paul H., 1982. Common law and statute law. Journal of Legal Studies 11, 205-33.

Schlesinger, R., Baade, H., Damaska, M., Herzog, P., 1988. Comparative Law. Case-TextMaterials. (New York, NY: The Foundation Press, Inc.).

Sokoloff, K., Engerman, S., 2000. Institutions, factor endowments, and paths of development in the new world, Journal of Economic Perspectives 14, 217-232.

Stigler, G.J., 1964. Public regulation of the securities market. Journal of Business, 37, 117-142.

Stulz, R. Williamson, R., 2003. Culture, openness, and finance. Journal of Financial Economics, forthcoming. 
Weber, M., 1958. The Protestant Ethic and the Spirit of Capitalism. Charles Scribner's Sons, New York, NY.

Wurgler, J., 2000. Financial markets and the allocation of capital. Journal of Financial Economics $58,187-214$.

Zingales, L., 1994. The value of the voting right: A study of the Milan stock exchange. The Review of Financial Studies 7, 125-148.

Zweigert, K., Kötz, H., 1998. Introduction to Comparative Law. Oxford University Press, New York, NY.

\section{Endnotes}

${ }^{1}$ Furthermore, see King and Levine (1993a,b), while panel investigations indicate that the relationship between finance and growth is not due to reverse causality (e.g., Beck, Levine, and Loayza (2000), Levine, Loayza, and Beck (2000), and Beck and Levine (2003). For a review of the literature, see Levine $(1997,2004)$.

${ }^{2}$ To qualify our approach, however, we recognize that many participants in the law and finance debate may not agree that the law and finance view is necessarily composed of the two parts mentioned above. This is not crucial for our review. We simply note that many contributors to the debate on the links between legal institutions and financial development examine (i) the impact of legal origin on property rights protection, support for private contractual arrangements, and investor protection laws, (ii) the impact of investor protection laws and their enforcement on financial development, or (iii) both. This review examines these different components.

${ }^{3}$ There may exist complex tradeoffs between law-making and enforcement conducted by the courts versus regulation. One difference is that courts enforce the law reactively, while regulators enforce laws proactively. For analyses of the conditions under which these different approaches work best, see Glaeser, Johnson, and Shleifer (2001) and Pistor and Xu (2002).

${ }^{4}$ Voltaire mocked it by writing, "When you travel in this Kingdom, you change legal systems as often as you change horses." (Quoted from Zweigert and Kötz, 1998, p. 80)

${ }^{5}$ See, Dawson (1968, p. 373). Also, while the Crown at times issued progressive reforms, the courts "...refused to apply the new laws, interpreted them contrary to their intent, or hindered the attempts of officials to administer them." (Merryman, 1985, p. 16)

${ }^{6}$ Robespierre even argued that, "the word jurisprudence ... must be effaced from our language." (Quoted from Dawson, 1968, p. 426)

${ }^{7}$ When the first commentary on the Code was published in 1805, Napoleon is said to have exclaimed, “My Code is lost!' (Quoted from Dawson, 1968, p.387)

${ }^{8}$ See, Posner (1973), Rubin (1977), and Priest (1977).

${ }^{9}$ The German legal scholar Karl von Savigny argued that the law of a people was a product of the history and culture of that people's development (Merryman, 1985, p. 30).

${ }^{10}$ See Zweigert and Kötz (1998, p. 264) and Glendon, et al. (1982, p. 96-100, 123-133).

${ }^{11}$ Coffee (2001) points to the superior performance of the Scandinavian countries relative to other Civil Law countries and even to Common Law countries and explains this with the high level of social cohesion in these countries.

12 There are two additional related issues. First, England was unified during the formative period of the Common law. This reduced political incentives for codification. Second, English courts 
were a liberalizing force that helped dismantle the feudal system and protected the rights of landowners against the Crown (Hayek, 1960). Whereas the French Revolution sought individual rights through strict prohibitions on the discretion of judges, England found liberty through an independent and influential judiciary.

${ }^{13}$ England did not try to replace Islamic, Hindu, or unwritten African law and the flexibility of the Common law eased its transfer. For instance, the English courts in India were instructed to apply Islamic or Hindu law depending on the faith of the parties in cases of inheritance, marriage, caste, etc. In Africa, judges were to apply the English law only to the extent that local circumstances permitted and matters were to be decided by equity and good conscience as rendered necessary by local circumstances (ZK, 1998, 225-9). While somewhat chaotic, this arguably set the stage for the evolution of an independent, dynamic common law in the post-colonial era.

${ }^{14}$ For example in the United States, corporate officers and directors have a legal responsibility to maximize firm value for shareholders. Macey and Miller (1993) argue that the efficiency justification for these broad fiduciary responsibilities is to fill in gaps because it is impossible to pre-contract for all contingencies. This gap-filling role of fiduciary duties can lower transactions costs and improve corporate governance by requiring directors to promote the interests of shareholder above their own interests.

${ }^{15}$ Proponents of the political channel argue that historically Germany had much more efficient institutions than France did. Citing Ertman (1997) and Finer (1997), LLS V (1998, 1999) note that Germany built a professional bureaucracy based on the military and professional civil servants, while France developed a patrimonial bureaucracy with strong links to political elites. Arguably, these differences have also worked to create German courts that are more independent from the State, more efficient at protecting private contracting rights, and less focused on the rights of the State than in France. Proponents of the legal-adaptability channel would counter that this cannot explain why other German legal origin countries, such as Korea and Japan have developed relatively efficient financial markets.

${ }^{16}$ For countervailing views and modifications, see Cooter and Kornhauser (1980), Cooter, Kornhauser, and Lane (1979), Blume and Rubinfeld (1982), Rubin (1982), Kaplow (1992), and Coffee (2000).

${ }^{17}$ Glaeser and Shleifer (2002) model the evolution of legal institutions, while Glaeser and Shleifer (2003) show that legal and regulatory institutions may evolve together and sometimes substitute for each other depending on specific conditions. For broad discussions of the co-evolution of legal, regulatory, and political institutions see Olson (1993), North (1981, 1990), Djankov, Glaeser, LaPorta, Lopez-de-Silanes, and Shleifer (2003b), and Barth, Caprio, and Levine (2003). Easterly and Levine (1997) show that ethnic division may shape the wide range of institutions and policies.

${ }^{18}$ Additional work further shows that Common law countries have significantly greater Market Capitalization than the combined group of civil law countries (BDL, 2001). 